\title{
TRADISI PEMBUATAN GERABAH DI DESA NGRENCAK KABUPATEN TRENGGALEK (Traditional Pottery of Ngrencak, Trenggalek Regency)
}

\author{
Hari Suroto \\ Balai Arkeologi Papua \\ Jalan Isele, Kampung Waena, Distrik Heram, Kota Jayapura 99358 \\ e-mail: hariprimitiveart@gmail.com
}

INFO ARTIKEL

Histori Artikel

Diterima: 25 Agustus 2017

Direvisi: 4 September 2017

Disetujui:30 Oktober 2017

Keywords:

Tradition,

Pottery,

Ngrencak

Kata kunci:

Tradisi,

Gerabah,

Ngrencak

\section{ABSTRACT}

The tradition of making and using pottery has existed since prehistoric times, this tradition is also found in Ngrencak Village, Trenggalek Regency. The purpose of this research is to know Ngrencak traditional pottery technology and the impact of modern culture on Ngrencak pottery tradition. Data collection techniques used in ethnoarkeologi studies are direct communication or direct contact with the data provider or often referred to as interviews, observation, and literature study. Ngrencak pottery-making technique is made by hand combined with stitching technique and rotary wheel. Ngrencak pottery faces rival plastic containers. It also depends on market demand.

\section{PENDAHULUAN}

Gerabah digunakan untuk menyebut jenis-jenis atau bentukbentuk benda pecah-belah terbuat dari tanah liat (Wahyudi, 2012:2). Tradisi gerabah merupakan tradisi yang dikenal sejak masa bercocok tanam di daerah pedalaman dan tradisi mencari hasil laut di daerah pantai pada masa prasejarah (Gardner, 1978: 142; Weinhold, 1983: 12). Gerabah relatif tahan air dan tahan panas api, sehingga dapat dipakai untuk sebagai wadah penyimpan (storage vessel) dan alat untuk memasak (cooking vessel). Pada masyarakat tertentu, gerabah merupakan benda yang dianggap memiliki fungsi serta arti penting di dalam kehidupan, baik dalam kehidupan sosial ekonomi maupun religi (Shepard, 1965: 348-352).

Jenis gerabah yang dikenal dalam tradisi gerabah di Indonesia yaitu jenis wadah dan jenis bukan wadah (Soegondho, 1995: 2). Bentuk 
gerabah berkaitan erat dengan fungsi (Nitihaminoto, 1983). Gerabah yang termasuk dalam kategori wadah antara lain tempayan, pasu, jambangan, kendi, cepuk, buli-buli, periuk, kendil, mangkuk, piring, cangkir, celengan, dan lain-lain; sedangkan yang termasuk kategori bukan wadah antara lain pelita, miniatur bangunan, figuran, dan unsurunsur bangunan seperti genteng, bata, saluran air dan lain-lain (Redaksi, 2008: 59).

Menurut Clive Orton, Paul Tyers dan Alan Vince dalam bukunya, Pottery in Archaeology, pembicaraan tentang gerabah selalu terkait dengan tiga dimensi arkeologi: bentuk, ruang, dan waktu, sebab gerabah dibuat dan digunakan pada waktu tertentu, dan digunakan untuk tujuan-tujuan tertentu (Orton et. al., 1993: 23). Selain itu unsur-unsur keindahan pada gerabah memiliki potensi untuk menggambarkan tingkat kepandaian teknologis masyarakat pembuatnya, sedangkan bentuk gerabah memiliki potensi memberi informasi mengenai kegiatan dan kebiasaan masyarakat yang menggunakannya (Shepard, 1965: 224; Rice, 1987; Sinopoli, 1991:119).

Prinsip dasar tentang pembuatan gerabah hampir tidak berubah sejak manusia membuatnya pertama kali pada masa neolitik, ribuan tahun yang lalu hingga kini. Proses dasarnya adalah tanah liat dibentuk menjadi benda yang diinginkan, lalu dikeringkan dan dibakar untuk membuat benda permanen (Thomas, 1982:4).
Pembuatan gerabah dapat dikategorikan sebagai suatu kemajuan dalam peradaban manusia, dalam pembuatan gerabah memiliki tahaptahap kerja yang selalu berurutan dan saling berkaitan. Tahapan-tahapan itu adalah pengadaan dan pengolahan (pencampuran) bahan, proses dan teknik pembentukan, dan pembakaran (Atmosudiro, 1998:1).

Tradisi pembuatan gerabah masih berlangsung di Desa Ngrencak, Kecamatan Panggul, Kabupaten Trenggalek. Untuk mengetahui teknologi gerabah tradisional Ngrencak yang meliputi bahan, teknik pembuatan, penyelesaian permukaan, teknik hias, dan teknik pembakaran maka dilakukan dengan studi etnoarkeologi. Kajian ini didasari penalaran induktif sehingga kedudukannya hanya bersifat memberikan contoh (sampel) untuk interpretasi, menyajikan kemungkinan awal (prior-probability), atau menilai kelayakan hipotesis. Studi etnoarkeologi sekedar memberi gambaran kemungkinan adanya persamaan antara gejala budaya masa lampau dengan budaya masa kini (Redaksi, 2008:188).

Saat ini gerabah Ngrencak kalah bersaing dengan wadah plastik. Sangat menarik untuk mengetahui kreatifitas pengrajin gerabah Ngrencak agar gerabah produksinya tetap eksis di pasaran.

Teknik pengumpulan data yang digunakan dalam studi etnoarkeologi yaitu komunikasi langsung atau 
kontak langsung dengan pemberi data atau sering disebut dengan wawancara, observasi perilaku berupa pengamatan pada aktivitas perajin gerabah, studi kepustakaan dengan memanfaatkan bahan-bahan tertulis baik buku maupun artikel ilmiah. Wawancara merupakan salah satu pengumpulan data yang paling efektif. Wawancara untuk memperoleh informasi sebanyak-banyaknya berkaitan dengan proses pembuatan gerabah mulai dari cara memperoleh bahan baku, proses penyiapan bahan, proses pembentukan, proses pengeringan, dan proses pembakaran. Alat-alat yang digunakan, variasi bentuk gerabah yang dibuat sekaligus fungsi dari masing-masing bentuk gerabah, serta peranannya dalam kehidupan masyarakat. Wawancara dilakukan terhadap pengrajin gerabah tradisional di Desa Ngrencak.

\section{PEMBAHASAN}

Umumnya pembuat gerabah di Desa Ngrencak adalah wanita. Pembuatan gerabah di Desa Ngrencak sudah turun-temurun. Penduduk setempat tidak ingat, sejak kapan desanya mulai dikenal sebagai produsen gerabah.

Bahan baku pembuatan gerabah diperoleh dari tegalan (ladang), pada umumnya untuk mendapatkan tanah liat dilakukan dengan cara membeli. $\mathrm{Di}$ dalam pengolahannya untuk menjadi bahan siap pakai, dibutuhkan bahan campuran pasir dengan perbandingan 4 : 1. Berdasarkan wawancara dengan pengrajin didapatkan bahwa apabila tanah liat ini kurang campuran pasirnya, maka gerabah akan hancur pada saat pembakaran. Campuran yang digunakan ini juga berdasarkan pengalaman mereka sehari-hari.

Pengetahuan perajin tentang tanah sebagai bahan gerabah terbatas pada apa yang telah mereka kenal dari pengalaman dan kebiasaan yang telah dimiliki para perajin generasi terdahulu. Pengolahan tanah liat untuk menjadi bahan baku siap pakai, melalui proses sebagai berikut tanah liat dijemur sambil dibuang kotoran yang terbawa. Alas yang dipakai untuk menjemur berupa tikar, anyaman bambu atau plastik dengan tujuan agar tanah liat tidak tercampur pasir kasar atau kerikil. Setelah setengah kering kemudian tanah liat diidek-idek (diinjak-injak) sambil diberi bahan campuran pasir. Lama proses penginjakan tanah sekitar 25 menit. Setelah proses penginjakan selesai, kemudian tanah liat tersebut ditutup dengan karung atau plastik agar tidak cepat kering.

Peralatan produksi gerabah di Desa Ngrencak terdiri atas:

1. Perbot (roda putarl slow-wheel) yaitu, alat berbentuk bulat, dibuat dari kayu, dan terdiri dari dua bagian. Berfungsi untuk membentuk bagianbagian gerabah misalnya bagian alas atau badan, teknik pemutarannya menggunakan tangan kanan atau ibu jari kaki. 
2. Tetep (tatap/ paddle anvi), adalah alat yang dibuat dari kayu berbentuk persegi panjang dengan tangkai pendek, berfungsi untuk meratakan, memadatkan, membesarkan dan menyimetriskan badan gerabah dengan cara dipukul-pukul.

3. Watu (batu) adalah alat yang dibuat dari batu berbentuk bulat gepeng, sedangkan pegangannya berbentuk bulat panjang. Bagian yang berbentuk bulat gepeng memiliki permukaan halus dan datar, berfungsi sebagai alat penahan pukulan-pukulan tatap.

4. Sirik, adalah alat yang dibuat dari bambu serta bentuk ujungnya runcing. Sirik ini berfungsi untuk melepaskan gerabah yang melekat di perbot, dengan demikian gerabah tersebut mudah diangkat dan dipindahkan.

5. Kerik, ialah alat yang dibuat dari sayatan bambu dan dibentuk melingkar menyerupai gelang, lebar sayatan 2 $\mathrm{cm}$ dan diameter lingkaran kurang lebih dapat dimasuki tangan orang dewasa. Lingkaran dibentuk dengan mengikat kedua ujungnya menjadi satu. Kerik dipergunakan untuk membersihkan kotoran-kotoran yang menempel di gerabah.

6. Dalim, adalah secarik kain bekas yang lebar. Fungsi dalim dipergunakan untuk menghaluskan bibir gerabah sehingga hasilnya lebih halus.

Proses pembuatan gerabah tradisional di Desa Ngrencak dapat diuraikan sebagai berikut: segumpal tanah liat diletakkan di atas perbot, dan besar kecilnya gumpalan tanah liat tergantung kebutuhan. Supaya tanah liat tidak terlalu lengket di perbot, maka permukaan perbot ditaburi pasir. Gumpalan tanah liat tersebut dipukulpukul dengan telapak tangan sehingga berongga. Selanjutnya perbot diputar perlahan-lahan dengan tangan kanan, sedangkan keempat jari tangan kiri di masukkan ke dalam rongga tanah liat dan ibu jari menempel pada dinding gerabah sebelah luar. Untuk pemutaran perbot supaya lebih cepat, dipakailah ibu jari kaki kanan. Dengan demikian rongga tanah liat menjadi semakin besar dan tinggi. Kemudian dibentuklah bibir gerabah dengan mempergunakan dalim yang sudah dicelupkan ke dalam air.

Dalam pembuatan gerabah,
besar kecilnya ukuran gerabah ditentukan oleh perasaan dan pengalaman seorang kundi (pembuat gerabah). Dari hasil pengamatan penulis, tampak adanya persamaan ukuran dan bentuk, kendati dalam proses pembuatan ini tidak dilakukan pengukuran.

Selanjutnya gerabah diangkat dari roda pemutar dengan memakai sirik. Setelah diangin-anginkan sebentar, kemudian dinding gerabah dipukul-pukul dengan tetep dan ditahan dengan watu. Proses penghalusan selanjutnya dilakukan dengan memakai secarik kain yang dibasahi. Setelah jadi, gerabah tersebut diangin-anginkan lagi kemudian dijemur langsung di bawah sinar matahari. Lokasi penjemuran umumnya di halaman rumah dan 
lebih sering dekat dengan tungku pembakaran.

Pembakaran

tahap akhir dalam pembuatan gerabah. Pembakaran mempengaruhi kualitas gerabah selain bahan baku. Keberhasilan dari pembakaran ini tergantung pada bahan bakar, pengaturan suhu, cara penyusunan gerabah selama pembakaran.

Setelah gerabah yang dijemur sudah kering, untuk menambah daya tahan agar tidak mudah pecah selanjutnya dibakar. Pembakarannya dilakukan di dalam tobong (tungku pembakaran terbuka berbentuk bulat). Pada dinding tungku bagian bawah terdapat lubang untuk memasukkan bahan bakar. Setelah gerabah yang akan dibakar diletakkan di dalam tungku, kemudian bagian atas gerabah ditutup jerami. Bahan bakar yang utama adalah kayu, untuk mengurangi biaya, biasanya perajin gerabah menggunakan klaras (daun pisang kering), daun bambu, damen (batang padi kering), ranting pohon, sabut kelapa, bonggol jagung serta titen (tanaman kedelai kering). Lama proses pembakaran kurang lebih satu setengah jam sampai dua jam. Selesai pembakaran, keesokan harinya gerabah-gerabah tersebut baru diambil dan dipindahkan ke dalam pondok penyimpan, gerabah disusun menurut jenis dan bentuk gerabah.

Pembakaran yang dilakukan dengan sempurna dan merata akan mendapatkan hasil yang baik, sedangkan pembakaran yang dilakukan tidak sempurna dan tidak merata akan menghasilkan gerabah yang jelek dan rapuh. Pembakaran yang tidak sempurna dapat dilihat dari bentuk gerabah yang jelek dan rapuh. Pembakaran yang tidak sempurna dapat dilihat dari bentuk gerabah yang mengalami retak-retak pada dindingnya dan pada penampangnya akan menampakkan perbedaan warna yang menandakan tidak tercampurnya bahan bakar dan panas yang tidak merata pada gerabah. Untuk mengetahui hasil pembakaran, gerabah yang sudah dingin dimasukkan ke dalam air. Bila dicelup ke dalam air gerabah ini retak, maka gerabah yang dibakar itu bermutu rendah.

Baik atau tidaknya pembakaran gerabah, dapat diketahui dari merata atau tidaknya warna pada bagian tengah (penampang lintang/ core). Biasanya gerabah yang pembakarannya mencapai oksidasi dan vitrifikasi akan memperlihatkan warna yang merata pada bagian tengah (dalam) dan bagian permukaan (luar). Pembakaran baik akan menghasilkan gerabah yang berwarna merah merata. Jenis gerabah yang dihasilkan terdiri dari damar sewu, yaitu periuk yang diberi lubang kecil di seluruh badannya dan digunakan untuk tempat lampu, khusus untuk penerangan pada kuburan ari-ari (plasenta) bayi. Gerabah jenis wajan, dandang, kuali digunakan untuk memasak. Sedangkan jembangan, gentong dan jun digunakan 
untuk tempat air. Pot bunga dan celengan memiliki bentuk unik dan diberi hiasan yang menarik.

Gerabah kalah bersaing dengan wadah berbahan plastik untuk keperluan yang sama. Meskipun demikian gerabah masih digunakan untuk membuat tape, merendam tepung singkong, dan menanak nasi. Gerabah telah menjadi bagian hidup yang tidak dapat terpisahkan karena kondisi lingkungan alam sekitar mendukungnya. Bentuk-bentuk tertentu, terbukti masih dipergunakan sebagai sarana pemenuhan kebutuhan seharihari, khususnya oleh masyarakat di sekitar Ngrencak. Hal ini karena mereka masih memanfaatkan kayu sebagai bahan bakar untuk memasak, sehingga dirasakan lebih praktis menggunakan gerabah. Gerabah tertentu misalnya tungku, masih memiliki peranan besar dalam aktivitas sehari-hari. Lingkungan alam mereka yang menyediakan kayu, merupakan faktor penyebab lebih memilih tungku daripada kompor gas.

Untuk tetap bertahan, perajin gerabah Ngrencak mengikuti selera pasar, mereka memproduksi gerabah disesuaikan dengan kebutuhan pasar. Publik lebih memilih wadah berbahan plastik yang dirasa lebih praktis dan awet, namun untuk mengolah makanan tradisional, menggunakan gerabah dinilai akan menghasilkan rasa yang lebih enak.

\section{PENUTUP}

Gagasan membuat gerabah merupakan tuntutan manusia dari dulu hingga kini yang masih tetap bertahan dengan modifikasinya. Ide mengolah tanah menjadi berbagai bentuk peralatan hidup ini merupakan keberhasilan manusia dalam mewujudkan pengalaman empirisnya mengenai sifat tanah liat yang lembek dan mudah dibentuk. Teknik pembuatan dengan tangan yang dipadukan dengan teknik tatap pelandas dan roda putar, merupakan upaya manusia untuk mengubah tanah liat sesuai bentuk yang dikehendaki yang sampai sekarang terus dipraktikan. Gerabah tetap memegang peranan penting dalam kehidupan manusia, meskipun banyak diterpa arus modernisasi.

Lemahnya sumber daya manusia, menyebabkan minimnya penguasaan teknologi dan rendahnya mutu dan kreasi. Keterbatasan semuanya ini akan berakibat menipisnya permintaan pasar. Kedua faktor tersebut jika mendapat penanganan serius maka kerajinan gerabah Ngrencak akan tetap mampu menghadapi saingan teknologi berbahan plastik. Bahkan kerajinan gerabah Ngrencak, mampu menjadi salah satu aset industri pariwisata, mengingat aktivitas pembuatan gerabah ini sudah menjadi bagian hidup para perajin setempat. Aktivitas pembuatan gerabah di Desa Ngrencak perlu dilestarikan dan dikembangkan. 
Oleh karena itu dinas terkait perlu lebih meningkatkan pembinaan dan bimbingan, disamping itu para seniman setempat perlu memberikan pengetahuan baru mengenai daya kreasi seni terhadap perajin gerabah Ngrencak. Sentuhan-sentuhan gaya kreasi yang bernuansa seni, akan menciptakan sesuatu jenis gerabah yang bagus dan menarik, sehingga membangkitkan konsumen untuk lebih bekerja sama. 


\section{DAFTAR PUSTAKA}

Atmosudiro, Sumijati. 1998. Manfaat Kajian Gerabah Masa Lalu bagi Pengembangan Kerajinan

Tembikar sebagai Penunjang Industri Pariwisata. Berkala Arkeologi XVIII (2). Balai Arkeologi Yogyakarta.

Gardner, E. J. 1978. The Pottery Technology of the Neolithic Period in Southeastern Europe. PhD Theses. University of California.

Nitihaminoto, Goenadi. 1983. Sebuah Konsep tentang Cara Penganalisaan Gerabah. Rapat Evaluasi Hasil Penelitian Arkeologi. Cisarua 8 - 13 Maret. Puslitarkenas. Him. 23-33.

Orton, Clive, Paul Tyers, dan Alan Vince. 1993. Pottery in Archaeology. New York: Cambridge University Press.

Redaksi, Dewan 2008. Metode Penelitian Arkeologi. Jakarta: Pusat Penelitian dan Pengembangan Arkeologi Nasional.

Rice, Prudence M. 1987. Pottery Analysis, A Sourcebook. Chicago: The University of Chicago Press.

Shepard, Anna O. 1965. Ceramics for the Archaeologist. Washington: Canergie Institution.

Sinopoli, Carla M. 1991. Approaches to Archaeological Ceramics. New York: Plenum Press.

Soegondho, Santoso. 1995. Tradisi Gerabah di Indonesia Dari Masa Prasejarah Hingga Masa Kini. Jakarta: Himpunan Keramik Indonesia.

Thomas, Guwilym. 1982. Step by Step Guide to Pottery. London: Hamlyn.

Wahyudi, Wanny Rahardjo. 2012. Tembikar Upacara di Candi-Candi Jawa Tengah Abad ke-8-10. Jakarta: Wedatama Widya Sastra.

Weinhold, R. 1983. The Many Faces of Clay. Edition Leipzig. 